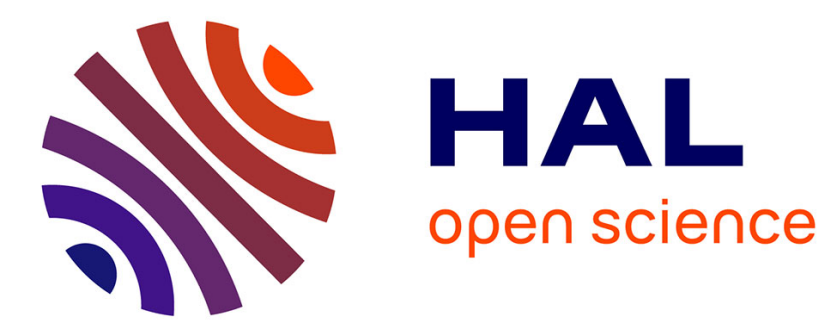

\title{
Economic development as major determinant of Olympic medal wins: predicting performances of Russian and Chinese teams at Sochi Games
}

Wladimir Andreff

\section{- To cite this version: \\ Wladimir Andreff. Economic development as major determinant of Olympic medal wins: predicting performances of Russian and Chinese teams at Sochi Games. International Journal of Economic Policy in Emerging Economies, 2013, 6 (4), pp.314-340. halshs-00971788}

\section{HAL Id: halshs-00971788 \\ https://shs.hal.science/halshs-00971788}

Submitted on 3 Apr 2014

HAL is a multi-disciplinary open access archive for the deposit and dissemination of scientific research documents, whether they are published or not. The documents may come from teaching and research institutions in France or abroad, or from public or private research centers.
L'archive ouverte pluridisciplinaire HAL, est destinée au dépôt et à la diffusion de documents scientifiques de niveau recherche, publiés ou non, émanant des établissements d'enseignement et de recherche français ou étrangers, des laboratoires publics ou privés. 


\title{
Economic development as major determinant of Olympic medal wins: predicting performances of Russian and Chinese teams at Sochi Games
}

\author{
Wladimir Andreff \\ 61, chemin du Pouget - 30350 Lédignan, France \\ E-mail: andreff@club-internet.fr
}

\begin{abstract}
Starting from an econometric model successfully used to explain and then predict the distribution of medal wins across nations at the Beijing Summer Olympics, a similar model is elaborated on with some different explanatory variables for estimating the determinants of medals won per nation at Winter Games. A Tobit estimation of the model based on data from 1964 to 2010 shows that GDP per capita, population, the endowment in ski and winter sports resorts, and a host country dummy are significant determinants of medal wins at Winter Olympics. Then the estimated model is used for predicting the sporting outcomes at the 2014 Sochi Games with a focus on Russia and China. The Russian team is expected to perform better than in Vancouver 2010 and to be ranked fourth behind the USA, Germany and Canada while the Chinese team would be ranked ninth, a performance doomed to improve in the future given China's swift economic development.
\end{abstract}

Keywords: econometric modelling; forecasting; Olympics; medal wins; sports economics; winter sports.

Reference to this paper should be made as follows: Andreff, W. (2013)

'Economic development as major determinant of Olympic medal wins: predicting performances of Russian and Chinese teams at Sochi Games', Int. J. Economic Policy in Emerging Economies, Vol. 6, No. 4, pp.314-340.

Biographical notes: Wladimir Andreff is Professor Emeritus at the University of Paris 1 Panthéon Sorbonne, Honorary President of the International Association of Sport Economists and European Sports Economics Association, honorary member of the European Association for Comparative Economic Studies, and former President of the French Economic Association (2007-08).

This paper is a revised and expanded version of a paper entitled 'Economic development as a major determinant of Olympic medal wins: predicting Russia's and China's performance at Sochi Games' presented at International Academic Conference 'Adjustment of Economic Structure and Sustainable Development: Perspectives in Russia and China', Yekaterinburg, Russia, 4-5 October 2012.

\section{Introduction}

Soon after Russia had obtained the organisation of Winter Olympics in Sochi 2014, the official expectation of Russian government became that the Russian Federation will win the Games she is going to host. Such expectation may have been strengthened by the outstanding Olympic performance of China at 2008 Beijing Summer Games since the host country has won the greatest number of gold medals and the second overall number 
of medals. However, is hosting the Games enough to win? Sports economists are used to explain a nation's performance at mega-sporting events by more variables than a single host country effect. Their explanatory variables usually encompass at least economic development, GDP size or growth, and often the magnitude of a nation's population. Thus, a next question is to check whether economic development is a significant and possibly major determinant of Olympic medal wins.

This paper attempts to respond the above question with a focus on Russia and China. These two countries are of particular interest. China is now ranked the second country in the world as regard its GDP and has the biggest population compared to any other country. Moreover, its rate of economic growth has been one of the fastest in the world over the past two decades. Economists are not surprised that Olympic performances of the Chinese team have improved with such fast economic development, and the 2008 Games confirmed it.

The former USSR has been for decades one of the best two Olympic performers in the world, at both Summer and Winter Games, ahead of or right behind the USA depending on the year. Economic and political transition and the break-up of the former Soviet Union have interrupted the series of high Olympic achievements by the Russian team (Poupaux and Andreff, 2007). With the transformational economic recession (Kornaï, 1994) the former Soviet sport system fell apiece (Andreff et al., 2012). Although Russia has recovered from recession after 1998, she did not get back to a number of Olympic medals comparable to the former times even when adding all other CIS countries to her medal count. Winning 72 medals at the 2008 Beijing Summer Games was considered as bad performance by Russian political and sporting authorities. With 15 medals won at the 2010 Vancouver Games, Russia ranked the sixth Winter Olympic country behind the USA, Germany, Canada, Norway and Austria; Russian authorities were disappointed again. The Russian performance at the 2012 London Games has improved up to 82 medals and new hope is that the Russian team would win the greatest number of medals at Sochi Olympics.

Consequently another question is to see whether Russia will be able to recover its former (Soviet) level of Olympic performance after nearly one decade of fast economic growth (1999-2007) and despite her muddling through the current global financial crisis since 2008. After a drop in her economic growth in 2008-2009, the Russian Federation returned to moderate growth in 2010 and recovered its pre-crisis output level in 2011. With a 142 million population and a $\$ 10,400$ gross national income (GNI) per capita on average in 2007-2011 - according to World Bank data, Russia is still a big and rather developed country which should eventually come back again to better Olympic performance. In particular, if she is compared to China with a $\$ 4,930$ GNI per capita and a 1,340 million population.

Facing a lack of economic studies devoted to Winter Games in the sports economics literature so far, this paper attempts a breakthrough in this area. To the best of our knowledge nobody has elaborated on an economic model for predicting medal wins at Winter Olympics and this is Forrest et al. (2012) contention as well. This contrasts with Summer Olympics for which about thirty studies have estimated the economic determinants of medal wins. It has been empirically verified that the number of medals a nation can make at Summer Games significantly depends on its population and GDP per inhabitant (Andreff, 2001). In the past decade, various papers started providing economic predictions of medal distribution per nation at the next Olympic Games (Bernard, 2008; Bernard and Busse, 2004; Johnson and Ali, 2004, 2008; Maennig and Wellebrock, 2008; 
Wang and Jiang, 2008). Our own model has exactly predicted $70 \%$, and correctly (with a small error margin) $88 \%$ of medal win totals per nation at the 2008 Beijing Olympics (Andreff et al., 2008; Andreff, 2010). The dependent variable is the same for Winter and Summer Games - the number of medals won by each participating nation. Though some independent variables of the Summer Games model have to be kept for Winter Games, some new variables must be introduced to capture the specificity of Winter Olympic sports. Thus, we will take stake of good predictions achieved with our Summer Olympics model to adapt it in view of forecasting the distribution of medal wins per nation at the 2014 Sochi Winter Games.

The paper reads as follows.

1 It starts with briefly reminding the most interesting methodologies at work in estimating Summer Olympics medal win distribution.

2 Then it shows how our own model has resolved this issue.

3 The model was used to predict medal totals per nation at the 2008 Olympics and the prediction was compared to actual outcomes reached by different nations in Beijing, a comparison which is absolutely rare in the literature so far.

4 A brief discussion provides justifications for keeping some similar variables in a model attempting to estimate the determinants of medal win distribution at Winter Olympics and for introducing some new variables that fit better with explaining winter sports performance; the discussion comes out with a somewhat different model.

5 The latter is estimated with data gathered for Winter Games from 1964 to 2010.

6 The estimated model is then used to predict the medal win distribution across nations at the 2014 Sochi Winter Olympics with a focus on the performance of Russia and China.

7 A conclusion makes the reader aware that such predictions are to be taken with a pinch of salt.

\section{Economic determinants of Olympic medals}

An assumption is widespread among sports economists: a nation's Olympic performance must be determined by her endowment in economic and human resources and the development of these resources. Thus, the starting point of most studies about the economic determinants of Olympic medal wins consists in regressing medal win totals on the nations' level of GDP per capita and population. Note that the growth in the number of medals won by one nation logically is an equivalent decrease in medal wins for all other nations participating to the Olympics. Therefore, if one wants to understand the Olympic performance of one specific nation, account must be taken of all other participating nations within the overall constraint of the allocated medals total during one Olympics contest.

In the first papers about the economic determinants of Olympic performance, GDP per capita and population were combined as explanatory variables with weather, nutrition, and mortality in the athletes' home country. Later on, in various studies up to 
the 1970s, other variables were considered as possible determinants of Olympic medal wins: protein consumption, religion, colonial past, newspapers supply, urban population, life expectancy, geographical surface area, military expenditures, judicial system and those sport disciplines taught at school in a nation. However, with the cold war period another significant variable emerged: the nation's political regime. The first Western work attempting to explain medal wins by the political regime of nations (Ball, 1972) immediately triggered a Soviet rejoinder (Novikov and Maximenko, 1972), both differentiating capitalist and communist regimes. The first two econometric analyses of Olympic Games (Grimes et al., 1974; Levine, 1974) exhibited that communist countries were outliers in regressing medal wins on GDP per capita and population: they were winning more medals than their level of economic development and population were likely to predict. A last variable has been introduced, namely since Clarke (2000), which is the influence on medal wins of being the Olympics host country. The latter gains more medals than otherwise due to big crowds of national fans, a stronger motivation of national athletes competing on their home ground and being adapted to local weather, and not tired by a long pre-Games travel.

More sophisticated econometric methodology was used in recent articles predicting Olympic medal wins, such as an ordered Logit model (Andreff, 2001), a Probit model (Nevill et al., 2002) and an ordered Probit model (Johnson and Ali, 2004). The most often quoted reference is Bernard and Busse (2004) whose Tobit model has been assessed as the most performing one and then used by Jiang and Xu (2005), Pfau (2006) and others. Bernard and Busse model is considered as the best one for estimating and predicting Olympic performance ${ }^{2}$; its two major independent variables - GDP per capita and population - explain the great bulk of medal distribution across participating nations. Three dummy variables capture a host country effect, the influence of belonging to Soviet-type and other communist (and post-Soviet and post-communist after 1990) economies as against being a non-communist market economy. These dummies are supposed to capture the impact of political regime on medal wins.

\section{Estimating the determinants of a nation sport performance at Summer Olympics}

Starting from Bernard and Busse, we have elaborated on a more specified model (Andreff et al., 2008) with a few improving emendations. The dependent variable is the number of medal wins ${ }^{3}$ per nation: $M_{i, t}$. Two primary explanatory variables are GDP per inhabitant in purchasing power parity dollars (PPP \$) and population. Both variables are four-year lagged $(t-4)$ under the assumption that four years are required to build up, train, prepare and make an Olympic team the most competitive in due time, four years later. That is, for explaining medal wins in 2008, 2004 GDP per capita and population were taken as estimators. A host dummy variable is used to capture a host country effect, i.e., the observed surplus of medals usually won by the national team of the host country. The first emendation to Bernard and Busse model regards the political regime variable: Bernard and Busse rather crudely divided the world into communist regimes and capitalist market economies which obviously fits with the cold war period. Since then, this is too crude when it comes to so-called post-communist transition economies (Andreff, 2004, 2007) in particular as regard the sports economy sector which has differentiated a lot across former socialist countries during their institutional 
transformation (Poupaux and Andreff, 2007). Such differentiation has translated into a scattered efficiency in winning Olympic medals after 1991 (Rathke and Woitek, 2008).

The country classification which is retained here distinguishes first Central Eastern European countries $(C E E C)$ which gave up a Soviet-type centrally planned economy in 1989 or 1990 , and transformed into a democratic political regime running a market economy: Bulgaria, the Czech Republic, Estonia, Hungary, Latvia, Lithuania, Poland, Romania, Slovakia (and Czechoslovakia until its 1993 split), Slovenia, and the GDR (until German reunification in 1990). Another commonality to this group is that these countries have all joined the European Union in 2004 or 2007. A second country group (TRANS) gathers new independent states (former Soviet republics) and some former CMEA member states which have started up a transition similar to the one in CEECs but are lagging behind in terms of transformation into a democratic regime and some are stalling on the path toward a market economy: Armenia, Azerbaijan, Belarus, Georgia, Kazakhstan, Kyrgyzstan, Moldova, Mongolia, Russia, Tajikistan, Turkmenistan, Ukraine, Uzbekistan and Vietnam. None of them has joined the EU so far or has really an option to do so. The next two groups have not been Soviet regimes properly speaking in the past, although they were both communist regimes and planned economies. In the first one (NSCOM), we sample those countries which have started up a transition process in the 1990s: Albania, Bosnia-Herzegovina, China, Croatia, Laos, Macedonia, Montenegro, and Serbia (and the former FSR Yugoslavia before the 1991 break-up). Two countries have not yet engaged into a democratic transformation and a market economy: Cuba and North Korea, and must be considered as still communist regimes $(C O M)$. All other countries are considered as capitalist market economies (CAPME), the reference group in our econometric estimations.

Then a last variable is introduced that captures the influence on Olympic performance of a specific sporting culture in a region. For example, Afghan ladies are not used to have much sport participation or to attend sport shows, even less to be enrolled in the Olympic team. As a result of these cultural (sometimes institutional) disparities, some nations are more specialised in one specific sport discipline such as weight-lifting in Bulgaria, Turkey and Armenia, marathon and long distance runs in Ethiopia and Kenya, cycling in Belgium and the Netherlands, table tennis, judo and martial arts in Asia, sprint in Caribbean islands and the USA, etc. It is not easy to design a variable that would exactly capture such regional sporting culture differences ${ }^{1}$, but it is assumed here that regional dummies may reflect them. For model estimation, the world is divided into nine 'sporting culture' regions: $A F S$, sub-Sahara African countries; $A F N$ : North African countries; NAM, North American countries; LSA, Latin and South American countries; EAST, Eastern European countries; $W E U$, Western European countries (taken as the reference region in our estimations); $O C E$, Oceania countries; $M N E$, Middle East countries; and $A S I$, (other) Asian countries.

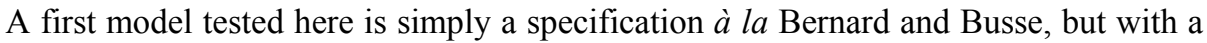
differently defined political regime variable. Estimation is based on a censored Tobit model since a non-negligible number of countries that participate to the Olympics do not win any medal. Therefore, a zero value of the $M_{i, t}$ dependent variable does not mean that a country has not participated and we work out a simple Tobit, not a Tobit 2 (with a two stage Heckman procedure). Contrary to Bernard and Busse, it is not assumed that preparing an Olympic team is timeless and, then, independent variables are four-year lagged behind the dependent variable. Thus, GDP per inhabitant is noted $(Y / N)_{i, t-4}$, measured in 1995 PPP dollars, and $N_{i, t-4}$ stands for population. Dummies are 
introduced to test whether the Olympics year is significant, taking 2004 as reference. These year dummies come out to be non-significant. In a second model, a data panel Tobit is adopted to take into account unobserved heterogeneity, whose test is significant ${ }^{4}$, and then estimation is with random effects. Sampled data ${ }^{5}$ encompass all Summer Olympics from 1976 to 2004, except 1980 and 1984 which are skipped out due to boycotts which have strongly distorted the medal distribution per country. The first specification (1) is:

$$
\begin{aligned}
M_{i, t}^{*}= & c+\alpha \ln N_{i, t-4}+\beta \ln \left(\frac{Y}{N}\right)_{i, t-4}+\gamma \text { Host }_{i, t} \\
& +\sum_{p} \delta_{p} \text { Political Regime }_{p, i}+\sum_{q} \kappa_{q} \text { Year }_{q, i}+\varepsilon_{i, t}
\end{aligned}
$$

where $\varepsilon_{i, t} \sim N\left(0, \sigma^{2}\right)$.

$M_{i, t}$ observation is defined by

$$
M_{i, t}= \begin{cases}M_{i, t}^{*} & \text { if } M_{i, t}^{*}>0 \\ 0 & \text { if } M_{i, t}^{*} \leq 0\end{cases}
$$

A second specification (2) is an emended variant of Bernard and Busse model including our more specific political regime variable, but also above-described dummies standing for regions of sporting culture $\left(\right.$ Regions $\left._{r, i}\right)$ :

$$
\begin{aligned}
M_{i, t}^{*}= & c+\alpha \ln N_{i, t-4}+\beta \ln \left(\frac{Y}{N}\right)_{i, t-4}+\gamma \text { Host }_{i, t} \\
& +\sum_{p} \delta_{p} \text { Political Regime }_{p, i}+\sum_{r} \rho_{r} \text { Regions }_{r, i}+u_{i}+\varepsilon_{i, t}
\end{aligned}
$$

where $\varepsilon_{i, t} \sim N\left(0, \sigma_{\varepsilon}^{2}\right)$ and $u_{i} \sim N\left(0, \sigma_{u}^{2}\right)$.

$M_{i, t}$ observation is defined by

$$
M_{i, t}= \begin{cases}M_{i, t}^{*} & \text { if } M_{i, t}^{*}>0 \\ 0 & \text { if } M_{i, t}^{*} \leq 0\end{cases}
$$

In a third specification (3), an additional variable $M_{i, t-4}$ is introduced on the right-hand side of model (2), just like Bernard and Busse did, though they did not comment why they proceeded in such a way. The justification here is that winning medals at the previous Olympics matters for an Olympic national team which usually expects and attempts to achieve at least as well as four years ago. Such inertial effect is all the more relevant that a nation is eager to win as many medals as possible from one Olympiad to the other (a sort of national 'Olympics cult ${ }^{\prime 6}$ ) and mobilise a lot of resources to succeed in. The resulting inertia differentiates those nations pulled by Olympics cult from those nations which are used to win zero or few medals. These two groups must be distinguished with using $M_{i, t-4}$, otherwise the prediction will be distorted. 
Table 1 Tobit estimation of medal wins at Summer Olympics

\begin{tabular}{|c|c|c|c|}
\hline Independent variables & $\begin{array}{c}\text { Tobit } \\
\text { model (1) }\end{array}$ & $\begin{array}{l}\text { Tobit (panel) } \\
\text { model (2) }\end{array}$ & $\begin{array}{l}\text { Tobit model (3) } \\
\text { with lagged M }\end{array}$ \\
\hline Log population $(t-4)$ & $9.14 * * *$ & $4.15^{* * *}$ & $2.15^{* * *}$ \\
\hline Log GDP per capita $(t-4)$ & $12.42 * * *$ & $5.44 * * *$ & $2.73 * * *$ \\
\hline Host & $24.37 * * *$ & $10.40 * * *$ & $10.04 * * *$ \\
\hline \multicolumn{4}{|c|}{ Political regime (ref. CAPME) } \\
\hline $\mathrm{COM}$ & $24.34 * * *$ & $11.18 * * *$ & $5.76^{* *}$ \\
\hline TRANS & $23.24 * * *$ & $20.97 * * *$ & $8.15^{* * *}$ \\
\hline CEEC & $21.43 * * *$ & $17.94 * * *$ & $6.71 * *$ \\
\hline NSCOM & $11.98 * * *$ & $8.06^{* * *}$ & $5.22 *$ \\
\hline \multicolumn{4}{|l|}{ Region (ref. WEU) } \\
\hline AFN & & $-4.45^{*}$ & -1.81 \\
\hline AFS & & $3.67^{*}$ & 0.75 \\
\hline NAM & & $7.93 * * *$ & 0.076 \\
\hline LSA & & 0.57 & -1.08 \\
\hline ASI & & $-4.34 * * *$ & $-2.58^{*}$ \\
\hline EAST & & $-5.53 *$ & -3.5 \\
\hline MNE & & $-5.00 * * *$ & $-2.47^{*}$ \\
\hline OCE & & $6.277 * *$ & 1.3 \\
\hline \multicolumn{4}{|l|}{ Year dummy (ref. 2004) } \\
\hline 1976 & 4.63 & & \\
\hline 1988 & -0.2 & & \\
\hline 1992 & 3.33 & & \\
\hline 1996 & 3.35 & & \\
\hline 2000 & 0.31 & & \\
\hline Medals $(t-4)$ & & & $0.95^{* * *}$ \\
\hline Constant & $-138 * * *$ & $-51.30 * * *$ & $-31.57 * * *$ \\
\hline Number of observations & 941 & 941 & 831 \\
\hline Log-likelihood value & $-1,646.1$ & $-1,551.5$ & $-1,224.2$ \\
\hline Pseudo $\mathrm{R}^{2}$ & 0.17 & 0.19 & 0.34 \\
\hline
\end{tabular}

All econometric estimations deliver significant results (Table 1). In the first estimation, all coefficients are positive and significant at a $1 \%$ threshold, except for year dummies. Thus, it is once again confirmed that medal wins are determined by GDP per capita, population and a host country effect. Political regime is also an explanatory variable, in particular in the case of communist and post-communist transition countries. The second estimation (Tobit/panel) all in all exhibits the same results. The coefficients of regional sporting culture are significant except for Latin America, an area in which the North American sporting culture may have permeated namely through Caribbean countries and Mexico (classified in NAM). 
Since Western Europe is the reference a significant coefficient with a positive sign means that a region performs relatively better than Western Europe in terms of winning Olympic medals (a negative sign means a lower relative performance than Western Europe). Sub-Sahara Africa, North America and Oceania perform better. It is a little bit surprising for Sub-Sahara African countries since they are among the least developed countries in the world (except South Africa), but such effect is due to a few African countries which are extremely specialised in one sport discipline where they are capable to win a non-negligible number of medals, such as Ethiopia and Kenya in long distance runs. With negative coefficients, North Africa, Asia, Eastern Europe and Middle East show a lower relative performance than Western Europe. It is not surprising for North Africa and the Middle East due to some restrictions to sporting culture in various countries. In the case of Asia, only few countries are really capable to win a significant number of medals (China, both Koreas, Mongolia). A surprise is the negative coefficient for Eastern European countries which are known as outliers or over-performers (given their GDP per capita and population). In fact, the negative coefficient results from the Political Regime variable which already captures their over-performance.

\section{Predicting medal wins at Beijing Olympics: comparison with observed outcomes}

Then model (3) was used to predict medal distribution at the 2008 Beijing Olympics:

$$
\begin{aligned}
M_{i, t}^{*}= & c+\alpha \ln N_{i, t-4}+\beta \ln \left(\frac{Y}{N}\right)_{i, t-4}+\gamma \text { Host }_{i, t} \\
& +\sum_{p} \delta_{p} \text { Political Regime }_{p, i}+\sum_{r} \rho_{r} \text { Regions }_{r, i}+\theta M_{i, t-4}+\varepsilon_{i, t}
\end{aligned}
$$

where $\varepsilon_{i, t} \sim N\left(0, \sigma^{2}\right)$.

$M_{i, t}$ observation is defined by

$$
M_{i, t}= \begin{cases}M_{i, t}^{*} & \text { if } M_{i, t}^{*}>0 \\ 0 & \text { if } M_{i, t}^{*} \leq 0\end{cases}
$$

Since a pooling estimation ${ }^{7}$ of model (3) is implemented, it may suffer from an endogeneity bias; the results may be biased by a correlation between the lagged endogenous variable and the error term. This issue is treated with a GMM dynamic panel (Arellano and Bond, 1991), a technique which provides estimated coefficients and predictions that are robust and close to those estimated with a Tobit model. Predictions have been first published (Andreff et al., 2008) only for a sub-sample of countries gathered in Table 2 .

The predicted first-rank winner was, as usual, the USA, followed by Russia and China, the latter benefitting from a host country effect at Beijing Games. Most developed and democratic market economies (CAPME) were forecast to be among the major medal winners together with some post-communist transition countries. The prediction for France was between 35 and 38 medals while the State Secretary for Sports was hoping that the French team would reach 40 medals (actually the achieved number was 41 medals). 
Table 2 Prediction of medal wins at Beijing Olympics

\begin{tabular}{|c|c|c|c|c|}
\hline & $\begin{array}{l}\text { Medals won } \\
\quad \text { in } 2004\end{array}$ & $\begin{array}{l}\text { Médial wins } \\
\text { predicted } \\
\text { in } 2008\end{array}$ & Lower bound & Upper bound \\
\hline \multicolumn{5}{|l|}{ CEEC } \\
\hline Bulgaria & 12 & 12 & 10 & 13 \\
\hline Hungary & 17 & 19 & 17 & 21 \\
\hline Poland & 10 & 14 & 12 & 16 \\
\hline Czech Republic & 8 & 10 & 8 & 12 \\
\hline Romania & 19 & 21 & 19 & 23 \\
\hline \multicolumn{5}{|l|}{ TRANS } \\
\hline Belarus & 15 & 17 & 14 & 20 \\
\hline Kazakhstan & 8 & 11 & 8 & 14 \\
\hline Russia & 92 & 96 & 93 & 100 \\
\hline Ukraine & 23 & 27 & 24 & 29 \\
\hline \multicolumn{5}{|l|}{ NSCOM } \\
\hline China & 63 & 80 & 73 & 86 \\
\hline Cuba & 27 & 29 & 25 & 33 \\
\hline \multicolumn{5}{|l|}{ CAPME } \\
\hline Germany & 49 & 52 & 50 & 54 \\
\hline Australia & 49 & 51 & 47 & 54 \\
\hline Canada & 12 & 15 & 13 & 18 \\
\hline USA & 102 & 106 & 103 & 110 \\
\hline France & 33 & 36 & 35 & 38 \\
\hline Great Britain & 30 & 47 & 32 & 35 \\
\hline Italy & 32 & 35 & 34 & 36 \\
\hline \multicolumn{5}{|c|}{ Less developed countries } \\
\hline Brazil & 10 & 12 & 10 & 14 \\
\hline South Korea & 30 & 30 & 27 & 32 \\
\hline Kenya & 7 & 2 & 1 & 4 \\
\hline Jamaica & 5 & 3 & 0 & 4 \\
\hline Turkey & 10 & 9 & 7 & 11 \\
\hline
\end{tabular}

Source: Andreff et al. (2008)

The publication of this article in France one month before the opening of Beijing Olympics rapidly became a hit in different French and European media and TV channels. First interviews focused on the predicted medal wins. In a second wave, after the Games end, interviewers became eager to know for which countries the model had provided correct or wrong prediction and, in the latter case, why were it so. This triggered the writing of a follow-up companion paper requested by the French National Institute for Sport and Physical Education (INSEP) to be included in its volume devoted to overall outcome for France at Beijing Olympics (Andreff, 2009). This paper systematically compared predictions and actual outcomes. 
The above model (3) provided good predictions regarding those 189 countries for which data were available and computable: $70 \%$ of observed results belong to the predicted confidence interval. If one assesses a model prediction as acceptable when its error margin is not bigger than a two-medal difference between ex ante prevision and ex post reality, then model (3) correctly predicted $88 \%$ of all Beijing Olympics results. The remaining unexplained 12\% (23 nations) account for sporting 'surprises' - unexpected results. Model (3) correctly predicted the first ten medal winners, except Japan (instead of Ukraine), missed only four out of the first twenty winners, although with a slightly different ranking. However, the most interesting results are witnessed when the model was clearly wrong in its prediction that basically happened for 23 countries, because this means that our five variables (plus the inertial variable) have not captured some core explanation of Olympics outcomes. Fortunately, economists are not capable to predict all the detailed Olympics results, otherwise why still convene the Games?

Which are the major 'surprises' delivered by ex post actual sporting results when compared with predictions? The first one is a quite bigger than expected number of medal wins by the Chinese team - all published predictions have been wrong in this respect. Model (3) has clearly underestimated the host country effect in China. Possibly, Chinese performance has also been boosted by some undetected doping ${ }^{8}$. A second surprise is the underperformance of the Russian Olympic team, the worst since the cold war. It was regarded so much 'catastrophic' that Vladimir Putin convened the highest decision makers of Russian sport to command a new Olympic policy likely to avoid a repeated disaster at the 2012 London Olympics. A policy which partly succeeded with 82 medals won in London. In the same vein, some other transition countries, namely Romania, have won fewer medals than expected in Beijing. The current state of reforming institutions and restructuring the whole sports sector in these countries has not been sufficiently captured in our model, despite our more refined political regime variable.

The last three significant surprises were Great Britain, Jamaica and Kenya, the latter being the only two developing countries ranked among the first twenty medal winners. Early preparation of a super-competitive team for the 2012 London Olympics may have been the cause for higher than expected outcomes of the British team, as it is suggested by Maennig and Wellebrock (2008) who have introduced a 'next Olympics host country' variable in their prediction. However, such future host country effect slightly improves the authors' forecast: 38 predicted medals as against 47 won by Great Britain. Without such effect model (3) predicted between 32 and 35 medals for Great Britain. British medals concentration in cycling (12 medals) may trace back again to undetected doping and/or deep specialisation of a nation in one sport discipline. The latter is the most likely explanation for Jamaican medals ${ }^{9}$ concentrated in sprint and Kenyan medals in long distance runs. Though such specialisation has been taken into account with the lagged $M_{i, t-4}$ variable - Kenya had won seven medals and Jamaica five in the same disciplines at Athens Olympics -, the inertia captured by this variable reveals to be insufficient.

\section{A model adapted to estimating the determinants of medal wins at Winter Olympics}

The sporting context of Winter Olympics is rather different compared with the one of Summer Olympics. In 1976, 92 countries had participated to Summer Olympics with 6,084 athletes while they were only 37 countries participating to Winter Olympics the 
same year, with 1,123 athletes (Table 3). In 2004, 201 countries were participating to Athens Olympics with 10,658 athletes whereas 80 countries had participated to the 2006 Winter Games in Turin with 2,651 athletes. Winter Olympics is a quite smaller mega-sporting event compared to Summer Games. However, the former has grown a lot during the lapse of time covered in this paper. The number of participating countries has increased from 36 in 1964 up to 82 in 2010 while the number of participating athletes has augmented from 1,091 to 2,629 . The number of medals to be won at Winter Olympics is smaller than the one observed at Summer Olympics (over 900 overall since 2000), but it has grown from 103 in 1964 up to 258 in 2010 . The number of nations having won at least one Winter Olympic medal has increased from 14 in 1964 to 26 in 2010 (as against a maximum of 80 countries at the 2000 Summer Games).

Table 3 Winter Olympic performances, 1964-2010

\begin{tabular}{lccccc}
\hline City & Year & $\begin{array}{c}\text { Participating } \\
\text { countries }\end{array}$ & $\begin{array}{c}\text { Countries } \\
\text { with } M>0\end{array}$ & $\begin{array}{c}\text { Overall number } \\
\text { of medals }\end{array}$ & $\begin{array}{c}\text { Participating } \\
\text { athletes }\end{array}$ \\
\hline Innsbruck & 1964 & 36 & 14 & 103 & 1091 \\
Grenoble & 1968 & 37 & 15 & 106 & 1171 \\
Sapporo & 1972 & 35 & 17 & 105 & 1008 \\
Innsbruck & 1976 & 37 & 16 & 111 & 1123 \\
Lake Placid & 1980 & 37 & 19 & 115 & 1072 \\
Sarajevo & 1984 & 48 & 17 & 117 & 1279 \\
Calgary & 1988 & 57 & 17 & 138 & 1424 \\
Albertville & 1992 & 63 & 20 & 171 & 1772 \\
Lillehammer & 1994 & 67 & 22 & 183 & 1747 \\
Nagano & 1998 & 72 & 24 & 205 & 2176 \\
Salt Lake City & 2002 & 77 & 24 & 234 & 2386 \\
Turin & 2006 & 80 & 26 & 252 & 2651 \\
Vancouver & 2010 & 82 & 26 & 258 & 2629 \\
\hline
\end{tabular}

Since population, GDP per inhabitant and the host country dummy variable have emerged as basic determinants of medal wins at Summer Olympics, they are kept in elaborating on a Winter Olympics model. Keeping GDP per capita in the model is particularly sensible because it is obvious from Table 4 that there is a relationship between the number of medal wins and the level of economic development. In Table 4, country groups are those defined by the World Bank. Developed market economies (DMEs) are countries with a GDP per inhabitant over \$10,725 in 2006; (newly) emerging economies (NMEs) are countries whose GDP per inhabitant is between $\$ 3,466$ and $\$ 10,725$; intermediary income (developing) countries (IICs) are those with a GDP per inhabitant between $\$ 876$ and $\$ 3,465$; least developed countries (LDCs) are those with a GDP per inhabitant below $\$ 876$. At Winter Olympics a concentration of medal wins on DMEs is witnessed whatever the number of participating DMEs. The average number of medal wins is always higher in DME and NME groups than in IICs and LDCs. Even with a growing number of participating countries - from 4 in 1964 to 20 in 2010 for IICs and from 3 to 13 for LDCs - these two country groups are not able to substantially increase their share in the medals total. In most Winter Games, LDCs have not won even a medal (except in 1992 and 1994 with just one medal win). 
Table 4 Uneven medal distribution at Winter Olympics by level of economic development

\begin{tabular}{|c|c|c|c|c|c|c|}
\hline Year & $\begin{array}{l}\text { Country } \\
\text { group }\end{array}$ & $\begin{array}{l}\text { Number of } \\
\text { medals }\end{array}$ & Mean: $m$ & $\begin{array}{l}\text { Coefficient of } \\
\text { variation: } \sigma / m\end{array}$ & $\begin{array}{l}\text { Number of } \\
\text { countries }\end{array}$ & $\begin{array}{c}\text { Countries } \\
\text { with } M>0\end{array}$ \\
\hline \multirow[t]{4}{*}{1964} & $\overline{D M E}$ & 77 & 3.67 & 1.27 & 21 & 12 \\
\hline & NEC & 26 & 3.25 & 2.71 & 8 & 2 \\
\hline & IIC & 0 & 0 & 0.00 & 4 & 0 \\
\hline & LDC & 0 & 0 & 0.00 & 3 & 0 \\
\hline \multirow[t]{4}{*}{1968} & DME & 83 & 3.95 & 1.13 & 21 & 11 \\
\hline & NEC & 23 & 2.56 & 1.70 & 9 & 4 \\
\hline & IIC & 0 & 0 & 0.00 & 5 & 0 \\
\hline & LDC & 0 & 0 & 0.00 & 2 & 0 \\
\hline \multirow[t]{4}{*}{1972} & DME & 71 & 3.38 & 1.12 & 21 & 13 \\
\hline & NEC & 34 & 4.25 & 1.58 & 8 & 4 \\
\hline & IIC & 0 & 0 & 0.00 & 4 & 0 \\
\hline & LDC & 0 & 0 & 0.00 & 2 & 0 \\
\hline \multirow[t]{4}{*}{1976} & DME & 64 & 2.67 & 1.26 & 24 & 13 \\
\hline & NEC & 47 & 5.22 & 1.97 & 9 & 3 \\
\hline & IIC & 0 & 0 & 0.00 & 4 & 0 \\
\hline & LDC & 0 & 0 & 0.00 & 0 & 0 \\
\hline \multirow[t]{4}{*}{1980} & DME & 67 & 2.91 & 1.24 & 23 & 14 \\
\hline & NEC & 47 & 5.22 & 1.88 & 9 & 4 \\
\hline & IIC & 1 & 0.25 & 2.00 & 4 & 1 \\
\hline & LDC & 0 & 0 & 0.00 & 1 & 0 \\
\hline \multirow[t]{4}{*}{1984} & DME & 61 & 2.26 & 1.54 & 27 & 13 \\
\hline & NEC & 55 & 5 & 1.96 & 11 & 3 \\
\hline & IIC & 1 & 0.17 & 2.41 & 6 & 1 \\
\hline & LDC & 0 & 0 & 0.00 & 4 & 0 \\
\hline \multirow[t]{4}{*}{1988} & DME & 78 & 2.44 & 1.56 & 32 & 13 \\
\hline & NEC & 57 & 5.18 & 2.10 & 11 & 3 \\
\hline & IIC & 3 & 0.3 & 3.17 & 10 & 1 \\
\hline & LDC & 0 & 0 & 0.00 & 4 & 0 \\
\hline \multirow[t]{4}{*}{1992} & DME & 141 & 4.41 & 1.58 & 32 & 16 \\
\hline & NEC & 26 & 1.86 & 3.30 & 14 & 2 \\
\hline & IIC & 3 & 0.25 & 3.48 & 12 & 1 \\
\hline & LDC & 1 & 0.2 & 2.25 & 5 & 1 \\
\hline \multirow[t]{4}{*}{1994} & DME & 149 & 4.52 & 1.58 & 33 & 16 \\
\hline & NEC & 23 & 1.44 & 3.99 & 16 & 1 \\
\hline & IIC & 10 & 1.67 & 0.76 & 12 & 4 \\
\hline & LDC & 1 & 0.83 & 0.49 & 6 & 1 \\
\hline
\end{tabular}

Notes: $\sigma$ : standard deviation; $M$ : number of medals per country. 
Table 4 Uneven medal distribution at Winter Olympics by level of economic development (continued)

\begin{tabular}{ccccccc}
\hline Year & $\begin{array}{c}\text { Country } \\
\text { group }\end{array}$ & $\begin{array}{c}\text { Number of } \\
\text { medals }\end{array}$ & Mean: $m$ & $\begin{array}{c}\text { Coefficient of } \\
\text { variation: } \sigma / m\end{array}$ & $\begin{array}{c}\text { Number of } \\
\text { countries }\end{array}$ & $\begin{array}{c}\text { Countries } \\
\text { with } M>0\end{array}$ \\
\hline 1998 & DME & 170 & 5.15 & 1.50 & 33 & 17 \\
& NEC & 21 & 1.4 & 3.33 & 15 & 2 \\
& IIC & 14 & 0.67 & 3.03 & 16 & 5 \\
& LDC & 0 & 0 & 0.00 & 8 & 0 \\
& DME & 197 & 5.97 & 1.64 & 33 & 16 \\
& NEC & 25 & 1.47 & 2.22 & 17 & 5 \\
& IIC & 12 & 0.67 & 2.94 & 18 & 3 \\
& LDC & 0 & 0 & 0.00 & 9 & 0 \\
& DME & 201 & 5.74 & 1.54 & 35 & 15 \\
& NEC & 36 & 2.4 & 2.33 & 15 & 7 \\
& IIC & 15 & 0.83 & 3.13 & 18 & 4 \\
& LDC & 0 & 0 & 0.00 & 12 & 0 \\
& DME & 207 & 6.09 & 1.60 & 34 & 16 \\
& NEC & 36 & 2.4 & 1.70 & 15 & 7 \\
& IIC & 15 & 0.75 & 3.35 & 20 & 3 \\
& LDC & 0 & 0 & 0.00 & 13 & 0 \\
\hline
\end{tabular}

Notes: $\sigma$ : standard deviation; $M$ : number of medals per country.

At first sight, the political regime seems to be less relevant as a variable that differentiates among the Winter Games medal winners; however it is kept in the model with some slight emendation compared to the Summer Olympics model. The reference country group remains CAPME for capitalist market economies; CEECs are those post-communist economies which have joined the EU in either 2004 or 2007; all the remaining post-communist economies are gathered in an EXCOM country group even though it would be sensible to consider Cuba and North Korea as still communist regimes (but their performance at Winter Games is negligible or nil).

A political regime variable might be a significant determinant (to be tested) of medal distribution per nation at Winter Olympics when looking at the data (Table 5). Being a centrally planned economy with some sort of communist regime was an advantage to win Winter Olympics medals until 1988. The average number of medal wins was higher in the EXCOM group than in the CEEC group and in the latter it was higher than in the CAPME reference group during this lapse of time, even though medals were concentrated on a small number of communist countries, namely the former USSR. The collapse of the communist regime seemingly had a significant impact on the number of medal wins which dramatically dropped in CEECs after 1990; it dropped much less significantly in other former communist countries, namely in the former Soviet Union, and recovered as soon as 1994 while the recovery in medal wins happened only in 2010 in CEECs. Such difference in momentum is probably due to a harsher shock of economic transition, a deeper and swifter transformation of the state-run sport system into a market sport economy in CEECs as compared with other post-communist countries, namely Russia. 
Table 5 Uneven medal distribution at Winter Olympics by political regime

\begin{tabular}{|c|c|c|c|c|c|c|}
\hline Year & $\begin{array}{l}\text { Country } \\
\text { group }\end{array}$ & $\begin{array}{l}\text { Number of } \\
\text { medals }\end{array}$ & Mean: $m$ & $\begin{array}{l}\text { Coefficient of } \\
\text { variation: } \sigma / m\end{array}$ & $\begin{array}{l}\text { Number of } \\
\text { countries }\end{array}$ & $\begin{array}{c}\text { Countries } \\
\text { with } M>0\end{array}$ \\
\hline \multirow[t]{3}{*}{1964} & CAPME & 77 & 2.85 & 1.53 & 27 & 12 \\
\hline & CEEC & 1 & 0.2 & 2.25 & 5 & 1 \\
\hline & EXCOM & 25 & 6.25 & 2.00 & 4 & 1 \\
\hline \multirow[t]{3}{*}{1968} & CAPME & 83 & 2.96 & 1.43 & 28 & 11 \\
\hline & CEEC & 10 & 1.67 & 1.35 & 6 & 3 \\
\hline & EXCOM & 13 & 4.33 & 1.73 & 3 & 1 \\
\hline \multirow[t]{3}{*}{1972} & CAPME & 71 & 2.84 & 1.29 & 25 & 13 \\
\hline & CEEC & 18 & 3 & 1.84 & 6 & 3 \\
\hline & EXCOM & 16 & 4 & 2.00 & 4 & 1 \\
\hline \multirow[t]{3}{*}{1976} & CAPME & 64 & 2.21 & 1.45 & 29 & 13 \\
\hline & CEEC & 20 & 3.33 & 2.31 & 6 & 2 \\
\hline & EXCOM & 27 & 13.5 & 1.41 & 2 & 1 \\
\hline \multirow[t]{3}{*}{1980} & CAPME & 67 & 2.48 & 1.41 & 27 & 14 \\
\hline & CEEC & 26 & 4.33 & 2.12 & 6 & 4 \\
\hline & EXCOM & 22 & 5.5 & 2.00 & 4 & 1 \\
\hline \multirow[t]{3}{*}{1984} & CAPME & 61 & 1.65 & 1.90 & 37 & 13 \\
\hline & CEEC & 30 & 5 & 1.92 & 6 & 2 \\
\hline & EXCOM & 26 & 5.2 & 2.13 & 5 & 2 \\
\hline \multirow[t]{3}{*}{1988} & CAPME & 78 & 1.7 & 1.98 & 46 & 13 \\
\hline & CEEC & 28 & 4.67 & 2.15 & 6 & 2 \\
\hline & EXCOM & 32 & 6.4 & 1.98 & 5 & 2 \\
\hline \multirow[t]{3}{*}{1992} & CAPME & 141 & 2.88 & 2.08 & 49 & 16 \\
\hline & CEEC & 3 & 0.38 & 2.79 & 8 & 1 \\
\hline & EXCOM & 27 & 4.5 & 2.03 & 6 & 3 \\
\hline \multirow[t]{3}{*}{1994} & CAPME & 146 & 3.32 & 1.96 & 44 & 15 \\
\hline & CEEC & 3 & 0.3 & 3.17 & 10 & 1 \\
\hline & EXCOM & 34 & 2.62 & 2.38 & 13 & 6 \\
\hline \multirow[t]{3}{*}{1998} & CAPME & 170 & 3.78 & 1.84 & 45 & 17 \\
\hline & CEEC & 4 & 0.4 & 2.43 & 10 & 2 \\
\hline & EXCOM & 31 & 1.82 & 2.53 & 17 & 5 \\
\hline \multirow[t]{3}{*}{2002} & CAPME & 196 & 3.92 & 2.15 & 50 & 15 \\
\hline & CEEC & 12 & 1.2 & 1.17 & 10 & 5 \\
\hline & EXCOM & 26 & 1.53 & 2.37 & 17 & 4 \\
\hline \multirow[t]{3}{*}{2006} & CAPME & 201 & 3.94 & 1.97 & 51 & 15 \\
\hline & CEEC & 12 & 1.2 & 1.17 & 10 & 6 \\
\hline & EXCOM & 39 & 2.05 & 2.67 & 19 & 5 \\
\hline \multirow[t]{3}{*}{2010} & CAPME & 204 & 3.92 & 2.14 & 52 & 15 \\
\hline & CEEC & 21 & 2.1 & 1.13 & 10 & 6 \\
\hline & EXCOM & 33 & 1.65 & 2.45 & 20 & 5 \\
\hline
\end{tabular}

Notes: $\sigma$ : standard deviation; $M$ : number of medals per country. 
With regards to the Regions dummy variable supposed to capture differences in sporting culture, it is not expected to be as much significant for Winter Olympics as it appeared to be for Summer Olympics. The reason is very simple: all those countries which participate to Winter Games have in common a sporting culture geared towards the practice of winter sports wherever they are located and whatever their overall sporting culture. This is confirmed by the fact that, contrary to Summer Olympics, many countries in the world do not participate to Winter Olympics. Thus, the regional dummy is skipped out from the Winter Olympics model.

If a country would like to develop a wide range of winter sports on its territory, making it able to train and select performing athletes, it could not significantly achieve it without some proper weather conditions, in particular enough snow coverage per year, and more than a minimal endowment in winter sports resorts and facilities ${ }^{10}$. These two new variables are to be introduced in the model. The first one is coined $S N O W$; it is a dummy differentiating countries as regard their average degree of annual snow coverage. Indeed, among those countries which have participated at least once to Winter Olympics, the degree of snow coverage is quite variable, but it is not easy to obtain a precise measure of snow coverage back to 1964. Thus, data and information provided by Maps of the World and the World Meteorological Organisation have been gathered regarding main climates, snow precipitations and temperature in order to build up the Snow dummy. The outcome in the sample of participating countries ${ }^{11}$ is as follows:

- $\quad P O L$ (a so-called 'polar' coverage in countries with a long duration of annual snow coverage): Belarus, Canada, Estonia, Finland, Iceland, Latvia, Lithuania, Mongolia, Nepal, Norway, Russia (by extension CIS and the former USSR), Sweden $=12$ countries

- $H I G H$ (local high winter snow coverage in otherwise temperate climate countries): Austria, Chile, Croatia, Czech Republic (by extension former Czechoslovakia), Denmark, France, Germany (by extension former GDR), Italy, Japan, Kyrgyzstan, Poland, Slovakia, Slovenia (by extension former Yugoslavia), Spain, Switzerland, Tajikistan, USA $=17$ countries

- MIDDLE (local middle snow coverage in temperate climate countries): Albania, American Samoa, Argentina, Armenia, Australia, Azerbaijan, Belgium, Bolivia, Bosnia-Herzegovina, Bulgaria, China (including Hong Kong), Cyprus, Fiji, Georgia, Great Britain, Greece, Guam, Hungary, Ireland, Israel, Lebanon, Luxembourg, Macedonia, Moldova, Netherlands, New Zealand, North Korea, Portugal, Peru, Romania, Serbia, South Africa, South Korea, Swaziland, Taiwan, Turkey, Ukraine, Uruguay $=39$ countries

- $L O W$ (countries with no or low snow coverage): Algeria, Bermuda, Brazil, Cameroon, Colombia, Costa Rica, Ethiopia, Ghana, Guatemala, Honduras, India, Iran, Jamaica, Kazakhstan, Kenya, Madagascar, Mexico, Morocco, Netherlands Antilles, Pakistan, Philippines, Senegal, Thailand, Trinidad and Tobago, Uzbekistan, Venezuela, Virgin Islands $=27$ countries. 
Table 6 Uneven medal distribution at Winter Olympics by level of snow coverage

\begin{tabular}{|c|c|c|c|c|c|c|}
\hline Year & $\begin{array}{l}\text { Country } \\
\text { group }\end{array}$ & $\begin{array}{l}\text { Number of } \\
\text { medals }\end{array}$ & Mean: $m$ & $\begin{array}{l}\text { Coefficient of } \\
\text { variation: } \sigma / m\end{array}$ & $\begin{array}{l}\text { Number of } \\
\text { countries }\end{array}$ & $\begin{array}{c}\text { Countries } \\
\text { with } M>0\end{array}$ \\
\hline \multirow[t]{4}{*}{1964} & POL & 60 & 8.57 & 1.06 & 7 & 5 \\
\hline & HIGH & 39 & 2.79 & 1,47 & 14 & 6 \\
\hline & MIDDLE & 4 & 0.31 & 2.03 & 13 & 3 \\
\hline & LOW & 0 & 0.00 & 0.00 & 2 & 0 \\
\hline \multirow[t]{4}{*}{1968} & POL & 43 & 6.14 & 0.94 & 7 & 5 \\
\hline & HIGH & 53 & 3.53 & 1.08 & 15 & 8 \\
\hline & MIDDLE & 10 & 0.83 & 3.12 & 12 & 2 \\
\hline & LOW & 0 & 0.00 & 0.00 & 3 & 0 \\
\hline \multirow[t]{4}{*}{1972} & POL & 38 & 6.33 & 1.00 & 6 & 5 \\
\hline & HIGH & 58 & 4.46 & 0.93 & 13 & 11 \\
\hline & MIDDLE & 9 & 0.64 & 3.77 & 14 & 1 \\
\hline & LOW & 0 & 0.00 & 0.00 & 2 & 0 \\
\hline \multirow[t]{4}{*}{1976} & POL & 46 & 6.57 & 1.44 & 7 & 5 \\
\hline & HIGH & 58 & 4.14 & 1.35 & 14 & 9 \\
\hline & MIDDLE & 7 & 0.47 & 3.30 & 15 & 2 \\
\hline & LOW & 0 & 0.00 & 0.00 & 1 & 0 \\
\hline \multirow[t]{4}{*}{1980} & POL & 47 & 5.88 & 1.30 & 8 & 5 \\
\hline & HIGH & 61 & 4.69 & 1.39 & 13 & 10 \\
\hline & MIDDLE & 7 & 0.50 & 2.18 & 14 & 4 \\
\hline & LOW & 0 & 0.00 & 0.00 & 2 & 0 \\
\hline \multirow[t]{4}{*}{1984} & POL & 59 & 7.38 & 1.17 & 8 & 5 \\
\hline & HIGH & 57 & 4.07 & 1.53 & 14 & 11 \\
\hline & MIDDLE & 1 & 0.05 & 4.60 & 19 & 1 \\
\hline & LOW & 0 & 0.00 & 0.00 & 7 & 0 \\
\hline \multirow[t]{4}{*}{1988} & POL & 52 & 6.50 & 1.47 & 8 & 5 \\
\hline & HIGH & 79 & 5.27 & 1.32 & 15 & 11 \\
\hline & MIDDLE & 7 & 0.33 & 4.64 & 21 & 1 \\
\hline & LOW & 0 & 0.00 & 0.00 & 13 & 0 \\
\hline \multirow[t]{4}{*}{1992} & POL & 61 & 5.55 & 1.51 & 11 & 5 \\
\hline & HIGH & 95 & 6.33 & 1.32 & 15 & 9 \\
\hline & MIDDLE & 15 & 0.68 & 1.94 & 22 & 6 \\
\hline & LOW & 0 & 0.00 & 0.00 & 15 & 0 \\
\hline \multirow[t]{4}{*}{1994} & POL & 73 & 6.08 & 1.55 & 12 & 6 \\
\hline & HIGH & 88 & 5.18 & 1.46 & 17 & 8 \\
\hline & MIDDLE & 18 & 0.72 & 2.14 & 25 & 6 \\
\hline & LOW & 4 & 0.31 & 2.74 & 13 & 2 \\
\hline
\end{tabular}

Notes: $\sigma$ : standard deviation; $M$ : number of medals per country. 
Table 6 Uneven medal distribution at Winter Olympics by level of snow coverage (continued)

\begin{tabular}{|c|c|c|c|c|c|c|}
\hline Year & $\begin{array}{l}\text { Country } \\
\text { group }\end{array}$ & $\begin{array}{l}\text { Number of } \\
\text { medals }\end{array}$ & Mean: $m$ & $\begin{array}{l}\text { Coefficient of } \\
\text { variation: } \sigma / m\end{array}$ & $\begin{array}{l}\text { Number of } \\
\text { countries }\end{array}$ & $\begin{array}{c}\text { Countries } \\
\text { with } M>0\end{array}$ \\
\hline \multirow[t]{4}{*}{1998} & POL & 75 & 6.25 & 1.42 & 12 & 6 \\
\hline & HIGH & 98 & 5.44 & 1.47 & 18 & 9 \\
\hline & MIDDLE & 30 & 1.03 & 2.56 & 29 & 8 \\
\hline & LOW & 2 & 0.15 & 3.67 & 13 & 1 \\
\hline \multirow[t]{4}{*}{2002} & POL & 73 & 5.62 & 1.44 & 13 & 7 \\
\hline & HIGH & 134 & 7.05 & 1.58 & 19 & 11 \\
\hline & MIDDLE & 27 & 0.96 & 2.33 & 28 & 6 \\
\hline & LOW & 0 & 0.00 & 0.00 & 17 & 0 \\
\hline \multirow[t]{4}{*}{2006} & POL & 93 & 7.15 & 1.30 & 13 & 8 \\
\hline & HIGH & 122 & 6.78 & 1.43 & 18 & 11 \\
\hline & MIDDLE & 37 & 1.12 & 2.70 & 33 & 7 \\
\hline & LOW & 0 & 0.00 & 0.00 & 16 & 0 \\
\hline \multirow[t]{4}{*}{2010} & POL & 86 & 6.62 & 1.39 & 13 & 8 \\
\hline & HIGH & 134 & 7.05 & 1.47 & 19 & 12 \\
\hline & MIDDLE & 37 & 1.12 & 2.95 & 33 & 5 \\
\hline & LOW & 1 & 0.59 & 0.41 & 17 & 1 \\
\hline
\end{tabular}

Notes: $\sigma$ : standard deviation; $M$ : number of medals per country.

The distribution of medal wins across these four country groups from the 1964 to 2010 Winter Olympics (Table 6) suggests that snow coverage might well be a significant determinant of medal wins in winter sports. Countries with high snow coverage, followed by countries with polar-like climate and snow coverage, concentrate the great bulk of medal wins at Winter Olympics. The number of participating countries with high snow coverage increased from 14 in 1964 up to 19 in 2010 while their number of medals won grew from 39 to 134. During the same lapse of time, the number of countries with polar-like snow coverage augmented from 7 in 1964 to 13 in 2010 whereas their number of medal wins increased from 60 to 86 . On the other hand, 13 countries with middle snow coverage had won only four medals in 1964; they were 33 participating at the 2010 Games where they won 37 medals. As regard countries with low (or no) snow coverage, the marked increase in their participation (from 2 to 17) did not translate into an impressive growth in medal wins (from 0 to 1 - with once four medals won in 1994 and once two medals in 2002). Snow coverage seems to be a differentiating factor among countries participating to Winter Olympics.

A second new dummy variable is introduced in the model to capture a country's endowment with winter sports resorts and facilities. Information is taken from data available on various websites describing ski resorts in different countries of the world, namely http://www.skiinfo.fr, http://www.sports-hiver.com, http://www.neigeski. com, http://www.levoyageur.net/stations, http://www.fr.snow-forecast.com, http://www. french-china.org. The RESORT dummy designed on the basis of such information consider a country as being endowed with many ski resorts and winter sports facilities when it has over 60 of them on its territory. A country with a number of skiing resorts between 5 and 60 is considered as having an average endowment by world standard. A 
country with a number of ski resorts and winter sports facilities below 5 is assessed and ranked as having few opportunities to win medals due to her short availability of resorts-facilities. The three country groups are comprised of:

- $\quad M A N Y$ winter sports resorts: Austria, Canada, former Czechoslovakia, France, Germany (GDR), Italy, Japan, Norway, Russia (CIS, USSR), Sweden, Switzerland, $\mathrm{USA}=12$ countries

- BETWEEN many and few winter sports resorts: Australia, Belgium, Bulgaria, Chile, China, Croatia, Czech Republic, Finland, Iran, Kyrgyzstan, Lebanon, Netherlands, New Zealand, Poland, Romania, Slovakia, Slovenia, South Korea, Spain, Turkey, Ukraine (former Yugoslavia) $=21$ countries

- $\quad F E W / N O$ winter sports resorts: Albania, Algeria, American Samoa, Argentina, Armenia, Azerbaijan, Belarus, Bermuda, Bolivia, Bosnia-Herzegovina, Brazil, Cameroon, Colombia, Costa Rica, Cyprus, Denmark, Ethiopia, Estonia, Fiji, Georgia, Great Britain, Ghana, Greece, Guam, Guatemala, Honduras, Hungary, Iceland, India, Ireland, Israel, Jamaica, Kazakhstan, Kenya, Latvia, Lithuania, Luxembourg, Macedonia, Madagascar, Mexico, Moldova, Mongolia, Morocco, Nepal, Netherlands Antilles, North Korea, Pakistan, Philippines, Portugal, Peru, Senegal, Serbia, South Africa, Swaziland, Thailand, Taiwan, Tajikistan, Trinidad and Tobago, Uruguay, Uzbekistan, Venezuela, Virgin Islands $=62$ countries.

Table 7 Medal distribution and winter sports resorts and winter sports facilities

\begin{tabular}{ccccccc}
\hline Year & $\begin{array}{c}\text { Country } \\
\text { group }\end{array}$ & $\begin{array}{c}\text { Number of } \\
\text { medals }\end{array}$ & Mean: $m$ & $\begin{array}{c}\text { Coefficient of } \\
\text { variation: } \sigma / m\end{array}$ & $\begin{array}{c}\text { Number of } \\
\text { countries }\end{array}$ & $\begin{array}{c}\text { Countries } \\
\text { with } M>0\end{array}$ \\
\hline 1964 & MANY & 89 & 7.42 & 0.97 & 12 & 10 \\
& BETWEEN & 13 & 0.87 & 2.98 & 15 & 3 \\
1968 & FEW/NO & 1 & 0.11 & 3.00 & 9 & 1 \\
& MANY & 91 & 7.00 & 0.57 & 13 & 12 \\
& BETWEEN & 15 & 1.00 & 2.56 & 15 & 3 \\
1972 & FEW/NO & 0 & 0.00 & 0.00 & 9 & 0 \\
& MANY & 89 & 6.85 & 0.69 & 13 & 13 \\
& BETWEEN & 16 & 1.14 & 2.31 & 14 & 4 \\
& FEW/NO & 0 & 0.00 & 0.00 & 8 & 0 \\
1976 & MANY & 95 & 6.79 & 1.15 & 14 & 12 \\
& BETWEEN & 15 & 0.94 & 2.38 & 16 & 3 \\
& FEW/NO & 1 & 0.14 & 2.71 & 7 & 13 \\
\hline \multirow{5}{*}{1980} & MANY & 95 & 6.79 & 1.11 & 14 & 4 \\
& BETWEEN & 18 & 1.28 & 2.06 & 14 & 2 \\
& FEW/NO & 2 & 0.22 & 2.00 & 9 & 13 \\
& MANY & 100 & 7.14 & 1.10 & 14 & 16 \\
\hline & BETWEEN & 16 & 1.00 & 3.25 & 18 & 3 \\
& FEW/NO & 1 & 0.56 & 0.43 & 16 & 13 \\
\hline
\end{tabular}

Notes: $\sigma$ : standard deviation; $M$ : number of medals per country. 
Table 7 Medal distribution and winter sports resorts and winter sports facilities (continued)

\begin{tabular}{ccccccc}
\hline Year & $\begin{array}{c}\text { Country } \\
\text { group }\end{array}$ & $\begin{array}{c}\text { Number of } \\
\text { medals }\end{array}$ & Mean: $m$ & $\begin{array}{c}\text { Coefficient of } \\
\text { variation: } \sigma / m\end{array}$ & $\begin{array}{c}\text { Number of } \\
\text { countries }\end{array}$ & $\begin{array}{c}\text { Countries } \\
\text { with } M>0\end{array}$ \\
\hline 1988 & MANY & 120 & 8.57 & 1.02 & 14 & 13 \\
& BETWEEN & 18 & 1.13 & 2.14 & 16 & 4 \\
1992 & FEW/NO & 0 & 0.00 & 0.00 & 27 & 0 \\
& MANY & 148 & 11.38 & 0.76 & 13 & 12 \\
& BETWEEN & 20 & 1.18 & 1.75 & 17 & 6 \\
1994 & FEW/NO & 3 & 0.09 & 4.22 & 33 & 2 \\
& MANY & 150 & 12.5 & 0.71 & 12 & 11 \\
& BETWEEN & 25 & 1.25 & 1.64 & 20 & 7 \\
& FEW/NO & 8 & 0.23 & 3.00 & 35 & 4 \\
& MANY & 155 & 12.92 & 0.66 & 12 & 11 \\
& BETWEEN & 44 & 2.00 & 1.86 & 22 & 9 \\
& FEW/NO & 6 & 0.16 & 3.06 & 38 & 4 \\
& MANY & 186 & 15.5 & 0.73 & 12 & 11 \\
& BETWEEN & 42 & 1.83 & 1.47 & 23 & 10 \\
& FEW/NO & 6 & 0.14 & 4.07 & 42 & 3 \\
& MANY & 191 & 15.92 & 0.59 & 12 & 11 \\
& BETWEEN & 55 & 2.50 & 1.52 & 22 & 11 \\
& FEW/NO & 6 & 0.13 & 3.85 & 46 & 4 \\
& MENY & 188 & 15.67 & 0.72 & 12 & 11 \\
& FEW/NO & 8 & 0.17 & 3.29 & 48 & 5 \\
\hline
\end{tabular}

Notes: $\sigma$ : standard deviation; $M$ : number of medals per country.

Participating countries with higher endowment in ski resorts and winter sports facilities are used to win an increasing number of Olympic medals from 89 in 1964 to 188 in 2010 (even 191 in 2006) while their number has always stood between 12 and 14 (Table 7). The number of participating countries with few or no resorts-facilities has grown from 9 in 1964 to 48 in 2010 whereas their number of medal wins has increased from 1 to 8 . The number of countries with an average endowment stands in between as to their medal wins. It seems that a shortage of ski resorts and winter sports facilities is a hindrance to win medals at Winter Olympics whereas medal wins benefit to well-endowed countries in terms of winter sports facilities.

Thus, the model is adapted to estimating the determinants of medal wins at Winter Olympics as follows:

$$
\begin{aligned}
M_{i, t}^{*}= & c+\alpha \ln N_{i, t-4}+\beta \ln \left(\frac{Y}{N}\right)_{i, t-4}+\gamma \text { Host }_{i, t} \\
& +\sum_{p} \delta_{p} \text { Political Regime }_{p, i}+\sum_{r} \rho_{r} \text { Snow }_{r}+\sum_{l} \lambda_{l} \text { Resort }_{l}+\varepsilon_{i, t}
\end{aligned}
$$

where $\varepsilon_{i, t} \sim N\left(0, \sigma_{\varepsilon}^{2}\right)$. 
$M_{i, t}$ observation is defined by

$$
M_{i, t}= \begin{cases}M_{i, t}^{*} & \text { if } M_{i, t}^{*}>0 \\ 0 & \text { if } M_{i, t}^{*} \leq 0\end{cases}
$$

and $N$ is a nation population, $Y / N$ is its GDP per inhabitant, both variables being four-year lagged for the same reason as with the Summer Olympics model, Host is a dummy identifying the country that hosts the Games, Political Regime is a dummy which captures the impact of political regime on medal wins, Snow is a dummy variable differentiating countries as regard their degree of annual snow coverage, and Resort is a dummy capturing the impact of ski resorts and winter sports facilities located in a country on medal wins.

\section{Economic determinants of medal win at Winter Olympic Games}

Model (4) is now used for estimating whether the above-listed variables are significant determinants of medal wins at Winter Olympics. Econometric testing covers all Winter Olympics from 1964 up to 2010. Data for population and GDP per inhabitant are taken from CHELEM data base (which retrieves and proceeds to consistency checks between World Bank and OECD data). A first specification M1 resorts to a left-hand censored Tobit model since a non-negligible number of countries that participate to Winter Olympics do not win any medal. Therefore, a zero value of the $M_{i, t}$ dependent variable does not mean that a country has not participated; a simple Tobit is worked out, not a Tobit 2 (with a two stage Heckman procedure). This first specification takes on board five explanatory variables: population, GDP per inhabitant, three dummies Host, Snow and Resort. The MIDDLE country group which contains the biggest number of countries is taken as the reference for the Snow dummy. With the same rationale, the most numerous FEW/NO country group is taken as the reference for the Resort dummy. In a second specification M2, the censored Tobit model includes in addition a Political Regime dummy. A third specification M3 is the one which will be used later on for prediction; it encompasses one more explanatory variable, i.e., the inertial variable $M_{i, t-4}$.

In all three specifications (Table 8), GDP per inhabitant and population are very significant determinants of medal wins at Winter Olympics with a positive sign. Medals are basically shared across developed economies with rather important population. More interesting is that the endowment in ski and winter sports resorts is also a very significant determinant of medal wins. Belonging to the BETWEEN country group significantly increases a nation's probability to win medals at Winter Olympics and it is even more so for those countries with many winter sports resorts. The very existence of winter sports resorts reflects a high capacity of having a winter sports practice in a country and, consequently, selecting experienced athletes in the national squad.

Snow coverage surprisingly does not appear as a significant determinant of Winter Olympics medal wins. Compared with MIDDLE coverage country group, polar-like countries have a significant probability to win more medals, but this probability is not significant for high snow coverage countries; the probability to win fewer medals is not significant for low snow coverage countries. A same result shows up with the other two specifications M2 and M3. Indeed, some countries with high snow coverage do not perform that well at Winter Games such as Tajikistan and Kyrgyzstan. It is not enough 
for a country to have snow, if it does not have enough ski resorts and winter sports facilities to train potential medal winners.

Table 8 Tobit estimations of medals won at Winter Olympics

\begin{tabular}{lccc}
\hline Independent variables & Tobit model M1 & Tobit model M2 & Tobit model M3 \\
\hline Log population $(t-4)$ & $2.006^{* * *}$ & $1.873^{* * *}$ & $0.787^{* * *}$ \\
Log GDP per inhabitant $(t-4)$ & $3.732^{* * *}$ & $6.958^{* * *}$ & $2.813^{* * *}$ \\
Host & 2.732 & $3.245^{*}$ & $3.874^{* * *}$ \\
Resort (ref. FEW/NO) & & & \\
$\quad$ MANY & $13.596^{* * *}$ & $15.633^{* * *}$ & $5.904^{* * *}$ \\
$\quad$ BETWEEN & $5.889^{* * *}$ & $6.951^{* * *}$ & $2.989^{* * *}$ \\
Snow (ref. MIDDLE) & & & \\
$\quad$ POLAR & $8.042^{* * *}$ & $5.390^{* * *}$ & $2.092^{* *}$ \\
$\quad$ HIGH & 0.922 & -1.292 & -0.286 \\
$\quad$ LOW & -1.906 & -0.313 & -0.653 \\
Political regime (ref. CAPME) & & & \\
$\quad$ CEEC & & $6.302^{* * *}$ & $3.186^{* * *}$ \\
$\quad$ EXCOM & & $10.077^{* * *}$ & $3.839^{* * *}$ \\
Medals $(t-4)$ & & $0.828^{* * *}$ & \\
Constant & $-24.198^{* * *}$ & $-34.252^{* * *}$ & -15.733 \\
Number of observations & 663 & 663 & 662 \\
Log-likelihood value & -957.881 & -928.749 & -811.892 \\
Pseudo-R & 0.221 & 0.245 & 0.339 \\
\hline
\end{tabular}

Notes: Significant at $* * * 1 \%, * * 5 \%$ and $* 10 \%$ threshold.

Introducing a Political regime dummy in the second specification improves the estimation overall (Pseudo- $\mathrm{R}^{2}$ increases). The host country dummy is significant (though at $10 \%$ ). Being a Central and Eastern European post-communist nation increases her probability to win medals at Winter Olympics and it is even more so for the EXCOM country group (CIS countries and all other non-Soviet former communist countries).

The third specification M3 is by far the best one with a marked improvement of Pseudo-R2. Moreover, all explanatory variables are significant except snow coverage with regards to high and low snow coverage countries. The inertial variable - medal wins at previous Winter Olympics - is significant as well and the host country dummy becomes significant at $1 \%{ }^{12}$. This model fits well for predicting medal wins at Sochi Winter Games.

\section{Economic prediction of medal wins at the 2014 Sochi Winter Olympics: Russia and China}

The prediction exercise based on model M3 takes CHELEM preliminary data for 2010 as regard population and GDP per inhabitant and then calculates the Sochi Games outcome in terms of medal wins (Table 9). The expected winner (first ranked country) is the USA with 36 medal wins, just like it happened in Vancouver 2010 with 37 medals. Germany 
ranks second with 28 medal wins while she has ranked first in 2006 (29 medals), 2002 (36 medals), 1998 (29 medals), 1992 (26 medals), and second in 2010 (30 medals). Canada takes over the third rank with 27 medals like in Vancouver 2010 (26 medals) and Turin 2006 (24 medals). France is expected to win 12 medals in Sochi (8th rank) as against 11 in Vancouver, 9 in Turin, 11 in Salt Lake City 2002, 8 in Nagano 1998, 5 in Lillehammer 1994, and 9 in Albertville 1992.

Table 9 Prediction of medal wins at Sochi Winter Olympics

\begin{tabular}{|c|c|c|c|c|}
\hline Countries & $\begin{array}{l}\text { Medals won } \\
\text { in } 2010\end{array}$ & $\begin{array}{c}\text { Medal wins } \\
\text { predicted in } 2014\end{array}$ & Lower bound & Upper bound \\
\hline USA & 37 & 36 & 33 & 38 \\
\hline Germany & 30 & 28 & 26 & 30 \\
\hline Canada & 26 & 27 & 25 & 28 \\
\hline Russia & 15 & 24 & 21 & 27 \\
\hline Norway & 23 & 24 & 22 & 25 \\
\hline Austria & 16 & 15 & 14 & 16 \\
\hline Sweden & 11 & 13 & 12 & 14 \\
\hline France & 11 & 12 & 11 & 13 \\
\hline China & 11 & 11 & 9 & 13 \\
\hline South Korea & 14 & 11 & 10 & 13 \\
\hline Switzerland & 9 & 9 & 8 & 10 \\
\hline Japan & 5 & 7 & 6 & 9 \\
\hline Italy & 5 & 7 & 6 & 8 \\
\hline Netherlands & 8 & 6 & 5 & 7 \\
\hline Poland & 6 & 6 & 4 & 8 \\
\hline Czech Republic & 6 & 6 & 4 & 7 \\
\hline Finland & 5 & 5 & 3 & 6 \\
\hline Australia & 3 & 3 & 1 & 4 \\
\hline Slovenia & 3 & 2 & 1 & 4 \\
\hline Croatia & 3 & 2 & 0 & 4 \\
\hline Slovakia & 3 & 2 & 0 & 3 \\
\hline Belarus & 3 & 1 & 0 & 3 \\
\hline
\end{tabular}

Winning 24 medals, Russia would rank fourth at Sochi Games. It is not enough to host Winter Games to be the winner. However, it would be a quite better performance than the disastrous 15 medals won in Vancouver (6th rank) and 13 medals in Salt Lake City (6th rank). Sochi Olympics might materialise the end of the deep transformation in the Russian sports system undertaken during the 1990s and the 2000s. This would be a sign of Russian recovery as a Winter Olympics sporting power but without coming back to the 1976-1988 'golden age' when the Soviet team was usually winning between one fifth and one quarter of all distributed medals. Economic and sporting systems' transformation triggered a shock on Russian and CIS medal wins whose share fell below $10 \%$ of medals total since 2002. In particular, the transformational recession has seriously affected Russia's GDP per capita downwards until 1998; the same roughly applies to other CIS 
countries. In our model, a decreasing GDP per capita explains a lower number of medal wins. A decreasing number of medals for Russia is (only partly) compensated by the emergence of Belarus, Kazakhstan and Ukraine as more or less regular medal winners at Winter Games since 1994 (Table 10).

Table 10 Medal wins by (post)-communist countries, 1964-2010

\begin{tabular}{|c|c|c|c|c|c|c|c|c|c|c|c|c|c|}
\hline Country & 1964 & 1968 & 1972 & 1976 & 1980 & 1984 & 1988 & 1992 & 1994 & 1998 & 2002 & 2006 & 2010 \\
\hline \multicolumn{14}{|l|}{ CEECs } \\
\hline Bulgaria & & & & & 1 & & & & & 1 & 3 & 1 & \\
\hline Czech Republic & & & & & & & & & & 3 & 3 & 4 & 6 \\
\hline Estonia & & & & & & & & & & & 3 & 3 & 1 \\
\hline Hungary & & & & & 1 & & & & & & & & \\
\hline Latvia & & & & & & & & & & & & 1 & 2 \\
\hline Poland & & & 1 & & & & & & & & 2 & 2 & 6 \\
\hline Romania & & 1 & & & & & & & & & & & \\
\hline Slovakia & & & & & & & & & & & & 1 & 3 \\
\hline Slovenia & & & & & & & & & 3 & & 1 & & 3 \\
\hline Former Czechoslovakia & 1 & 4 & 3 & 1 & 1 & 6 & 3 & 3 & & & & & \\
\hline Former GDR & & 5 & 14 & 19 & 23 & 24 & 25 & & & & & & \\
\hline Former Yugoslavia & & & & & & 1 & 3 & & & & & & \\
\hline CEECs $/$ medals total $\%$ & 1.0 & 9.4 & 17.1 & 18.0 & 22.7 & 26.5 & 22.5 & 1.7 & 1.6 & 1.9 & 5.4 & 4.8 & 8.1 \\
\hline \multicolumn{14}{|l|}{ CIS countries } \\
\hline Belarus & & & & & & & & & 2 & 2 & 1 & 1 & 3 \\
\hline Kazakhstan & & & & & & & & & 3 & 2 & & & 1 \\
\hline Russia & & & & & & & & & 23 & 18 & 13 & 22 & 15 \\
\hline Ukraine & & & & & & & & & 2 & 1 & & 2 & \\
\hline Uzbekistan & & & & & & & & & 1 & & & & \\
\hline Former USSR & 25 & 13 & 16 & 27 & 22 & 25 & 29 & $23^{*}$ & & & & & \\
\hline CIS/medals total (\%) & 24.3 & 12.3 & 15.2 & 24.3 & 19.1 & 21.4 & 21.0 & 13.4 & 16.9 & 11.2 & 6.0 & 9.9 & 7.4 \\
\hline \multicolumn{14}{|l|}{ Other EXCOM } \\
\hline China & & & & & & & & 3 & 3 & 8 & 8 & 11 & 11 \\
\hline Croatia & & & & & & & & & & & 4 & 3 & 3 \\
\hline North Korea & & & & & & & & 1 & & & & & \\
\hline
\end{tabular}

Note: *CIS unified squad

The confidence interval for Russian medal wins is between 21 and 27 (Table 9). So that, in the worst case, Russia may win less medals in 2014 than at the 1994 and 2006 Winter Games, which would not be considered as very rewarding by Russian sports authorities. Moreover, the model predicts no medal win for Kazakhstan and Ukraine at 2014 Sochi Games and only one for Belarus.

The transformational recession lasted a shorter lapse of time in CEECs than in CIS countries. Nevertheless, the transition shock has triggered a dramatic drop in CEEC medal wins at Winter Games. The recovery in medal wins was quite slower than 
economic recovery since the sports sector was not a top priority in the transition strategy backed by Washington organisations (the IMF and World Bank). The most spectacular shock on medal wins in CEECs derives from German unification in 1990. The former GDR also enjoyed a sort of 'golden age' from 1972 to 1988 with between 14 and 25 medal wins at Winter Olympics ${ }^{13}$. At the 1992 Winter Games, the unified German team, taking stake of East German athletes, outperformed (with 26 medals) all participating countries including the CIS unified team (23 medals). Since then Germany became top performer at Winter Olympics with the biggest number of medals won from Albertville 1992 to Turin 2006 (except Lillehammer 1994, 2nd rank behind Norway, and Vancouver 2010, 2nd rank behind the USA). At the 2014 Sochi Games, model (4) forecasts only 16 medal wins for CEECs taken altogether, which would be a step back compared to the 2010 recovery with 21 medals though better than 12 medal wins in 2002 and 2006.

China would rank 9th at Sochi Games according to the model prediction. In fact, China has appeared as a new Winter Olympics winner since 1992, and more basically since 1998 (ranked 11th in 1998, 10th in 2002, 9th in 2006 and 8th in 2010) even though this cannot compare with the Chinese outstanding performance at the Summer Games hosted in Beijing. Thus, it is not surprising that the model predicts again 11 medal wins for China in 2014, but note that the upper bound of the confidence interval for China is 13 medals. If the Chinese team performs very well, it may even pretend to the 7 th rank in terms of medal wins at Sochi Games. The swift economic development of China since the 1990s has obviously had an impact on the nation capacity to win more Olympics medals in general and including at Winter Olympics. However, China's performance at Winter Games is less outstanding than at Summer Games. This is probably due to a number of ski resorts and winter sports facilities which are not yet proportionate to the size of Chinese population and its increasing purchasing power. To the best of our knowledge, the number of winter sports participants and the number of ski resorts are both rapidly increasing these days in China. Probably, some time is still required to have a mass of winter sports participants huge enough to select a very performing national Chinese team of winter sports athletes. Hosting some future Winter Olympics in China may boost the expansion of ski resorts and winter sports practice throughout Chinese population. The candidature of a Chinese city close to a winter sports site would probably be in the prospects of some Chinese authorities in the medium term.

\section{Conclusions: economic prediction and surprising sporting outcomes}

All above predictions must be taken with a pinch of salt. This is namely due to surprising sporting outcomes. Indeed, there are many unexpected sporting outcomes observed ex post - i.e., achieved outcomes markedly different from the forecast - even though it happens more with the FIFA World Cup than Summer Olympics (Andreff, 2010). Unexpected or surprising outcomes of a sport contest have not been analysed so far. They happen when opponents in a sport contest have clearly uneven sporting forces, and the underdog wins the favourite. Elaborating on a metrics to quantify surprising sporting outcomes should be a promising avenue for further research. It will be possible to check after the 2014 Sochi Games whether these Winter Olympics were characterised with many or few surprising outcomes. 
As regard the host country, Russia is not likely to win the biggest number of medals at Sochi Winter Games. If she was to make it with more than 27 medals, then being ranked third with Canada, one would be allowed to conclude that she performed well, better than expected on the basis of the above economic model. Such a good performance should be due to exceptional efforts of Russian athletes and coaches before and during Sochi Games. If Russia would win less than 21 medals, we could join Prime Minister Medvedev and President Putin in complaining that the Russian winter sports team should really have done better - or that it was unexpectedly bad lucky. When it comes to the Chinese winter sports team, if it would be able to win a significantly higher number of medals than 11 in Sochi, this must be considered as an excellent outcome. If the number were to fall quite below 11, it should be considered as a counter-performance. Not to be expected so far!

\section{References}

Andreff, M., Andreff, W. and Poupaux, S. (2008) 'Les déterminants économiques de la performance olympique: Prévision des médailles qui seront gagnées aux Jeux de Pékin', Revue d'Economie Politique, Vol. 118, No. 2, pp.135-169.

Andreff, W. (2001) 'The correlation between economic underdevelopment and sport', European Sport Management Quarterly, Vol. 1, No. 4, pp.251-279.

Andreff, W. (2004) 'Would a second transition stage prolong the initial period of post-socialist economic transformation into market capitalism?', European Journal of Comparative Economics, Vol. 1, No. 1, pp.7-31.

Andreff, W. (2007) Economie de la transition: La transformation des économies planifiées en économies de marché, Bréal, Paris.

Andreff, W. (2009) 'Comparaison entre les prévisions et les médailles gagnées aux Jeux de Pékin, in INSEP', Pékin 2008: Regards croisés sur la performance sportive olympique et paralympique, INSEP, Secrétariat d'Etat aux Sports, Paris, pp.241-247.

Andreff, W. (2010) 'Economic modeling and prediction of Summer Olympic medal wins and FIFA World Cup semi-finalists', Conference Economie, politique et société: nouveaux défis et perspectives, 28-29 October, Higher School of Economics, Moscow.

Andreff, W., Bril, O. and Poupaux, S. (2012) 'Sport in Russia', in Sobry, C. (Ed.): Sports Governance in the World. A Socio-Historic Approach, Vol. II: The Transition in Central and Eastern European Sport, Editions Le Manuscrit, Paris, pp.195-218.

Arellano, M. and Bond, S. (1991) 'Some tests of specification for panel data: Monte Carlo evidence and an application to employment equations', Review of Economic Studies, Vol. 58, No. 2, pp.277-297.

Ball, D. (1972) 'Olympic Games competition: structural correlates of national success', International Journal of Comparative Sociology, Vol. 13, Nos. 3-4, pp.186-200.

Bernard, A.B. (2008) Going for the Gold: Who Will Win the 2008 Olympic Games in Beijing [online] http://mba.tuck.dartmouth.edu/pages/faculty/andrew.bernard/Beijing2008 (accessed 30 March 2008).

Bernard, A.B. and Busse, M.R. (2004) 'Who wins the Olympic Games: economic resources and medal totals', Review of Economics and Statistics, Vol. 86, No. 1, pp.413-417.

Clarke, S. (2000) 'Home advantage in the Olympic Games', in Cohen, G. and Langtry, T. (Eds.): Proceedings of the Fifth Australian Conference on Mathematics and Computers in Sport, Conference proceedings, University of Technology Sydney, Sydney, pp.43-51.

Dryden, N. (2006) 'For power and glory: state-sponsored doping and athletes' human rights', Sports Lawyers Journal, Vol. 13, No. 1, pp.1-40. 
Forrest, D., Ceballos, A., Flores, R., McHale, I.G., Sanz, I. and Tena, J.D. (2012) 'Explaining and forecasting national team medals totals at the Summer Olympic Games', in Maennig, W. and Zimbalist, A. (Eds.): International Handbook on the Economics of Mega Sporting Events, pp.208-24, Edward Elgar, Cheltenham.

Grimes, A.R., Kelly, W.J. and Rubin, P.H. (1974) 'A socioeconomic model of national olympic performance', Social Science Quarterly, Vol. 55, No. 4, pp.777-782.

Hoffmann, R., Chew Ging, L. and Ramasamy, B. (2002) 'Public policy and olympic success', Applied Economic Letters, Vol. 9, No. 8, pp.545-548.

Jiang, M. and Xu, L.C. (2005) 'Medals in transition: explaining medal performance and inequality of Chinese provinces', Journal of Comparative Economics, Vol. 33, No. 1, pp.158-172.

Johnson, D. and Ali, A. (2004) 'A tale of two seasons: participation and medal counts at the Summer and Winter Olympic Games', Social Science Quarterly, Vol. 85, No. 4, pp.974-993.

Johnson, D. and Ali, A. (2008) Predictions for Medal Counts at Beijing Olympics, Based on Economic Model [online] http://faculty1.coloradocollege.edu/ djohnson/Olympics/ Beijing2008predictions.pdf (accessed 30 March 2008).

Kornaï, J. (1994) 'Transformational' recession. The main causes', Journal of Comparative Economics, Vol. 19, No. 1, pp.39-63.

Levine, N. (1974) 'Why do countries win Olympic medals? Some structural correlates of Olympic Games success: 1972', Sociology and Social Research, Vol. 58, No. 2, pp.353-360.

Maennig, W. and Wellebrock, C. (2008) 'Sozioökonomische Schätzungen olympischer Medaillengewinne. Analyse-, Prognose- und Benchmarkmöglichkeiten', Sportwissenschaft, Vol. 38, No. 4, pp.131-148.

Nevill, A., Atkinson, G., Hughes, M. and Cooper, S. (2002) 'Statistical methods for analyzing discrete and categorial data recorded in performance analysis', Journal of Sports Sciences, Vol. 20, No. 10, pp.829-844.

Novikov, A.D. and Maximenko, A.M. (1972) 'The influence of selected socio-economic factors on the levels of sports achievements in the various countries', International Review of Sport Sociology, Vol. 7, No. 1, pp.27-44.

Pfau, W.D. (2006) Predicting the Medal Wins by Country at the 2006 Winter Olympic Games: An Econometric Approach, January, National Graduate Institute for Policy Studies, Tokyo, mimeo.

Poupaux, S. and Andreff, W. (2007) 'The institutional dimension of the sports economy in transition countries', in Parent, M.M. and Slack, T. (Eds.): International Perspectives on the Management of Sport, pp.99-124, Elsevier, Amsterdam.

Rathke, A. and Woitek, U. (2008) 'Economics and the Summer Olympics: an efficiency analysis', Journal of Sports Economics, Vol. 9, No. 5, pp.520-537.

Wang, J. and Jiang, Y. (2008) 'Logarithm model prediction for 2008 Beijing Olympic Games', International Journal of Sports Science and Engineering, Vol. 2, No. 1, pp.47-51.

\section{Notes}

1 Hoffmann et al. (2002) consider that an important determinant of Olympic successes lies in the degree to which sport and sporting activities are embedded in a nation's culture. The proxy used to capture such determinant is the total number of times a country has hosted Olympic Summer Games between 1946 and 1998. Our regional variable does not intend to capture only a nation's sporting culture but how much it is specific (different from the one of nations located in a different geographical area).

2 It was certainly so until the most recent publication by Forrest et al. (2012).

3 Bernard and Busse use the percentage of medal wins per country $i$ for $M_{i, t}$ instead. Our regressions are calculated with both the absolute number of medals (Table 1) and the percentage of medals per country, and the results are not significantly different. 
4 A test of maximum likelihood shows that the rho coefficient is significant $(\operatorname{Pr}=0.00)$.

5 The data panel is not balanced since the number of existing countries in the world has increased between 1976 and 2004, namely due to the breakup of the former Soviet Union, former Yugoslavia and former Czechoslovakia (+20 countries), only partly compensated by the reunifications of Germany and Yemen ( -2 countries).

6 Which has been fuelled in particular by the cold war, but it has not vanished yet in a number of countries.

7 A test of maximum likelihood shows that the rho coefficient is not significant $(\operatorname{Pr}=0.26)$ which allows to choose a pooling estimation.

8 This issue is discussed in depth in Andreff et al. (2008) explaining why it was not possible to integrate doping among independent variables despite the fact that we wished to do so.

9 Some Jamaican sprint finalists have been controlled positive in doping tests during the weeks after the Beijing Games, which may be another explanatory variable.

10 Some exceptions are neglected here such as Dubai with its ski resort in a country without any natural snow coverage and without even a second winter sports facility in the country.

11 Some countries which have participated to Winter Olympics are excluded from the sample since data about population and GDP cannot be traced back to 1964. They are: Andorra, Caiman Islands, Liechtenstein, Monaco, Montenegro, Porto Rico, and San Marino. No big medal winner.

12 A fourth specification has also been tested including the Regions dummy used in the Summer Olympics model. For three regions the test does not provide any result since these regions have never won a medal at Winter Games. For most regions, the variable is not significant even at a $10 \%$ threshold.

13 For more specific determinants of Olympics performances reached by the communist GDR: Dryden (2006). 